Pace University

DigitalCommons@Pace

$1-1-2004$

\title{
"Which One of You Did It? Criminal Liability for "Causing or Allowing" the Death of a Child
}

Lissa Griffin

Elisabeth Haub School of Law at Pace University

Follow this and additional works at: https://digitalcommons.pace.edu/lawfaculty

Part of the Criminal Law Commons, and the Juvenile Law Commons

\section{Recommended Citation}

Lissa Griffin, "Which One of You Did It?" Criminal Liability for "Causing or Allowing" the Death of a Child, 15 Ind. Int'I \& Comp. L. Rev. 89 (2004), http://digitalcommons.pace.edu/lawfaculty/470/.

This Article is brought to you for free and open access by the School of Law at DigitalCommons@Pace. It has been accepted for inclusion in Pace Law Faculty Publications by an authorized administrator of DigitalCommons@Pace. For more information, please contact dheller2@law.pace.edu. 


\title{
"WHICH ONE OF YOU DID IT?" CRIMINAL LIABILITY FOR “CAUSING OR ALLOWING” THE DEATH OF A CHILD
}

\author{
Lissa Griffin ${ }^{*}$
}

\section{INTRODUCTION}

In the United States, the statistics on child abuse and homicide are absolutely staggering. Homicide is the leading cause of death for children under one year of age, and at least five children die each day from abuse and neglect by those who are obligated to protect them. ${ }^{1}$ Regrettably, although the homicides are attributable to the acts of persons who supposedly care for the children, it frequently is difficult to identify the culprits.

Child homicide creates special problems for prosecutors. By its nature, child homicide occurs most frequently in the privacy of the home. In a case involving multiple defendants-for example, two parents or caretakers-proof frequently is unavailable to identify the person who actively caused physical harm to the child (the "active abuser") and the person who, although aware of the active abuse, failed to prevent it, or failed to get medical treatment for the injured child (the "passive abuser"). It frequently is difficult to determine the relative culpability of the responsible parties. Because there are no living witnesses, the prosecution cannot prove where or exactly how the crime took place, or who, aside from an active abuser, was present. While forensic evidence may prove that the death was non-accidental and the approximate time of death, such evidence still may be unable to clarify who committed the fatal act or acts, or who was present when they were committed. Given these circumstances, even though it is clear that someone caused the death of a helpless child, those who committed the acts may either not be charged, or if prosecuted, will likely be acquitted or have the charges dismissed.

Neither U.S. courts nor the state legislatures have dealt with this problem. While much has been written about the omission-liability of a passive child abuser, all of the literature assumes that the prosecution has been able to in fact identify and differentiate the passive from the active abuser. ${ }^{2}$ No state court or

- Professor of Law, Pace University School of Law. The author wishes to thank Professor Bennett L. Gershman and Professor Phil Bates for their invaluable assistance. The title of this article is based on the title of an article by Professor Glanville Williams. Professor Williams's article addresses the same problems of prosecuting child homicide addressed in this article, but in the context of the United Kingdom. "Causing or Allowing the Death of a Child or Vulnerable Adult" is the title of legislation recently passed by the English Parliament to address the same problems.

1. See U.S. Dep't of Health and Human Serv., A Nation's Shame: Fatal Chind ABUSE AND NEGLECT IN THE UNITED STATES 16 (1995).

2. See, e.g., Christine A. Martin, Murder by Child Abuse - Who's Responsible after State 
legislature has proposed an effective method of overcoming the evidentiary insufficiency inherent in this most horrible of crimes-the murder of an innocent child.

In the absence of any effective domestic remedy, one needs to look to foreign law. Confronted with similarly horrifying statistics and similar prosecutorial problems, the English Parliament ${ }^{3}$ recently enacted legislation to solve the problems inherent in prosecuting multiple defendants in a child homicide case.

Part II of this article analyzes how current U.S. criminal law addresses the problem of securing a homicide conviction where multiple defendants are accused in a child's non-accidental death. Part III sets forth the English response: a statute that includes (1) a new substantive crime; (2) a permissible negative inference against a defendant who fails to account for the nonaccidental death of a child for whom he or she is responsible; and (3) delay of a motion to dismiss for failure to establish a prima facie case until after the defense has been presented or the jury has been allowed to draw the negative inference. The English response in light of U.S. law is analyzed, and its efficacy in meeting the prosecutor's evidentiary problems is evaluated. The article concludes that the English response should be adopted here, despite the controversial proposal that the jury in such a case be allowed to draw a negative inference against a defendant who bears responsibility for a child, who fails to account for that child's non-accidental death.

\section{PROSECUTING MULTIPLE DEFENDANTS FOR CHILD HOMICIDE: EXISTING U.S. LAW}

\section{A. Difficulties in Establishing Guilt}

Where a child suffers a non-accidental death, and more than one defendant is involved, there are two methods of establishing culpability. First, the culpability of both parties for homicide may be established under an accomplice liability theory. Second, where accomplice liability cannot be proven, one defendant may be prosecuted for the homicide as an active abuser, and the other may be prosecuted for either reckless homicide (generally, manslaughter), or under a protection or prevention statute, such as endangering the welfare of a child. However, in either scenario, the prosecutor must

v. Jackson, 24 SEATtuE U.L. REv. 663 (2000); Nancy A. Tanck, Note, Commendable or Condemnable? Criminal Liability for Parents who Fail to Protect their Children from Abuse, 1987 WIS. L. REv. 659 (1987); Ricki Rhein, Note, Assessing Criminal Liability for the Passive Parent: Why New York Should Hold the Passive Parent Criminally Liable, 9 CaRdozo WOMEN's L.J. 627 (2003); Bryan A. Liang \& Wendy L. Macfarlane, Murder by Omission: Child Abuse and the Passive Parent, 36 HARV. J. ON Legis. 397 (1999); Jean Peters-Baker, Note, Punishing the Passive Parent; Ending a Cycle of Violence, 65 U. MO. KAN. CITY L. REV. 1003 (1997).

3. This article makes reference to "England" and "English" rather than to the United Kingdom because the legislation as enacted would apply to the courts in England and Wales, and not in the entire United Kingdom. 
establish which of the defendants inflicted the fatal injury and which was aware that the injury occurred.

These problems are illustrated in the case of People v. Wong. ${ }^{4}$ In Wong, a three-month old infant died of shaken baby syndrome. ${ }^{5}$ The shaking had occurred in the apartment of the child's two babysitters, Eugene and Mary Wong, with whom the child resided six days a week. After a lengthy investigation, in which the Wongs gave incomplete and contradictory statements, the prosecution charged Mr. and Mrs. Wong with first and second degree manslaughter, and endangering the welfare of a child. ${ }^{6}$

At trial, the prosecution's medical evidence proved that the fatal shaking of the child occurred in the one-bedroom apartment at some time during a two and one-half hour period at night, in which the defendants acknowledged to the police that they were both at home and caring for the child. ${ }^{7}$ The infant slept in the defendants' bedroom. A medical expert testified that the shaking required to cause shaken baby syndrome does not necessarily leave visible exterior marks; that the infant would "cry sharply" and then, within 30 minutes, slip into a gradual coma that could resemble sleep. ${ }^{8}$ There was also medical evidence that "prompt medical attention can prevent fatality" in cases such as this one."

At the close of the prosecution's case, the defense moved to dismiss the charges against both defendants. The defense argued that since the prosecution could not prove who was the active and who was the passive abuser, the defendants could not be found guilty. ${ }^{10}$ In response, the prosecution argued that each defendant was culpable because, even though there was no proof of the defendants' respective roles, at least one of them had shaken the baby and the other had failed to intervene. ${ }^{11}$ The motion to dismiss was denied. ${ }^{12}$

Both defendants were convicted of manslaughter in the first and second degrees, and endangering the welfare of a child. ${ }^{13}$ On appeal, the court modified the judgment by dismissing the convictions for manslaughter in the first degree on the unrelated ground that the finding that the defendants had acted or failed to act "with intent to cause serious physical injury" was against the weight of the evidence. ${ }^{14}$ The court upheld the convictions for

4. 619 N.E.2d 377 (N.Y. 1993).

5. Id. at 380 . Shaken baby syndrome occurs when an infant under the age of one year is shaken violently, causing the head to snap back and forth. Id. The movement of the brain inside the head leads to ruptured blood vessels, hemorrhage, and swelling, but does not necessarily result in any visible injuries. $I d$.

6. N.Y. PENAL LAW $§ \$ 125.15,125.20,260.10$ (Consol. 2004).

7. Wong, 619 N.E.2d at 379.

8. Id. at 380 .

9. Id.

10. Id.

11. Id.

12. Id.

13. Id.

14. See N.Y. Penal LaW $\S 125.20$; see also People v. Wong, 588 N.Y.S.2d 119 (N.Y. App. Div. 1992). 
manslaughter in the second degree and for endangering the welfare of a child. Over a two-justice dissent, the court rejected the contention that the prosecution had failed to produce sufficient evidence of the time and place of death to show that the passive defendant failed to perform a duty imposed by law. ${ }^{15}$

The defendants appealed to the New York Court of Appeals, which, where the court reversed the remaining convictions and dismissed the indictment against both defendants. ${ }^{16}$ The court agreed with the defense that: (1) the evidence was insufficient to prove who was the active and who was the passive abuser; (2) the evidence was insufficient to prove the guilt of the passive defendant; and (3) without evidence that both defendants were guilty, the convictions of both defendants had to be reversed. ${ }^{17}$

According to the court, without proof of exactly when and where the death occurred, the passive defendant's mere presence in the apartment during the relevant time period was insufficient to establish criminal liability. The court held that the prosecution failed to prove that the passive defendant had a duty to seek medical care, because there was insufficient evidence that the passive parent knew of the need for such care. While both defendants admitted being awake and tending to the child during a two and one-half hour period when the shaking was likely to have occurred and although the apartment had only one bedroom, there was no proof that the two were continuously together. According to the court, it was certainly likely that one of them left the room at some point. Contrary to the State's contention that it would have been coincidence for the shaking to occur at that time, the Court considered it quite plausible that a person inclined to abuse a child would wait until he was alone with the child to do so. ${ }^{18}$ Thus, absent proof that the passive defendant was personally aware that the shaking had occurred, he could not be convicted. Without that evidence, the jury could not have concluded that the passive defendant was aware of a risk that the infant would die without prompt medical attention. Without that awareness, there was no liability for failing to act: ${ }^{19}$

In the absence of any evidence to show how, or at least where, the abusive acts had occurred and which room or rooms the two defendants had been in, there was no basis for the jury to infer that the 'passive' defendant had actually witnessed the shaking - a form of abuse that would leave no visible external marks. $^{20}$

15. Wong, 619 N.E.2d at 380 .

16. Id. at 383 .

17. Id. at 381-383.

18. Id. at 382 .

19. Id. at $382-83$.

20. Id. at 382 . 
A theory that was not pursued by the prosecutors in Wong, which might have established that the passive abuser should have known or did know about the risk of serious physical injury, is based on the history of abuse of other children who had been left in the Wongs' care. In the lower court, the prosecution proceeded on the theory that the active defendant had shaken the child, and the passive defendant was personally aware of the shaking, and therefore of the risk that the infant would die without prompt medical treatment. In upholding the defendants' convictions, however, the Appellate Division suggested a different theory: "[T]hat the 'passive' defendant was criminally culpable for knowingly permitting his or her spouse to tend to a crying child in a late-night situation that was likely to provoke abuse.",21

This theory is premised on the evidence admitted at trial to demonstrate that other children entrusted to the Wongs' care had also been abused. ${ }^{22}$ As the majority in the appellate division explained, evidence that there had been prior vicious acts of abuse, that both defendants had been interviewed by a social worker about those acts, and that the defendants participated in the decision to continue their babysitting service established both the knowledge of the passive defendant and a "blatant disregard for the welfare of the child." 23 Moreover, both defendants made statements admitting that they were aware that the infant had been crying for two hours in the early morning before the fatal abuse occurred. "Under such circumstances, commonly known to be an exhausting, frustrating and emotionally wearing experience, to leave the child at the mercy of a known child abuser would be, without more, a conscious disregard of a substantial risk of death . ...,24

As the court of appeals noted, however, this theory was not submitted to the jury. The evidence of prior incidents of abuse was admitted only to rebut a defense of accident or mistake. ${ }^{25}$ Had the theory been properly raised, the

\section{Id at 383 .}

22. Wong, 588 N.Y.S.2d at 122 . As summarized by the Appellate Division, that evidence is as follows:

In March 1988, 18-month-old Kevin Hung, when taken by his father to the hospital after spending a month with the Wongs, was found to have a second degree burn on the sole of his foot, bruises on his face and body, and fractures, one recent and one several weeks old, in each leg. As a result, he was hospitalized for 13 days. Earlier, on a visit, Kevin's father had observed a burn on the child's mouth, but had dismissed it as an accident when Mrs. Wong told him that Kevin had tried to taste some hot soup which she had left out to cool. In June of 1988, shortly before Kwok-Wei Jiang came into the Wongs' care, 11/2month-old Jenny Chan was taken to the hospital by her father when he visited her at the Wongs' and saw that her face was badly discolored and that she was completely unresponsive. Mrs. Wong claimed that she had found the baby in that condition when she awoke and suggested that it was due to an "internal problem." Jenny was hospitalized for three days.

Id.

23. Id. at 125 .

24. Id. at 125-26.

25. Wong, 619 N.E.2d at 383.

Heinonline -- 15 Ind. Int'l \& Comp. L. Rev. 93 2004-2005 
defendants might have been convicted on the grounds that one of them was the principal and one the accomplice.

Reluctantly, the Court of Appeals reversed both convictions:

We are duty bound to reverse these two defendants' convictions because the alternative - incarcerating both individuals for a crime of which only one is demonstrably culpable - is an unacceptable option in a system that is based on personal accountability and presumes each accused to be innocent until proven otherwise. ${ }^{26}$

What becomes clear from Wong is that none of the weapons in the prosecutor's traditional arsenal was adequate to avoid this result. First, there were no eyewitnesses. Second, the forensic investigation and resulting evidence, although complete, were not sufficient. Evidence regarding cause of death and time of death could not establish the defendants' culpability without proof of where each of the defendants was when the death occurred. Moreover, absent visible bruises or signs of distress, there was insufficient proof that the passive defendant actually witnessed the shaking or was otherwise aware that anything fatal had occurred or that anything needed to be done to help the child. Without such proof, there was no mens rea to establish liability based on the failure to act.

Of course, the prosecutor could have granted immunity to one of the defendants, and thus secured an eyewitness. ${ }^{27}$ But in the context of child homicide, with the absence of important information, the prosecutor's choice of which party to immunize is particularly vulnerable to error. The role of the respective parties in causing the child's death is exactly what the prosecutor does not know. Even if the prosecutor guesses correctly, a guilty party could go free. ${ }^{28}$ But if the prosecutor guesses wrongly, the active, more culpable abuser goes free. Unlike other situations requiring a decision to grant immunity, in this case the prosecutor has a full fifty percent chance of being wrong. On the other hand, it may be that both parties are equally responsible, for example, on an aiding and abetting theory. Thus, although it is clear that someone is responsible for the child's death, the power to grant immunity may not help at all, or may be surrounded by so much guess work that there is an increased and unacceptable risk that a child's murderer will be freed. ${ }^{29}$

26. Id. (Bellacosa, J., dissenting).

27. See N.Y. CRIM. Proc. LAW $\S 50.10$ (Consol. 2004) (providing full transactional immunity in New York).

28. The passive abuser, for example a mother, may have violated a duty to prevent commission of an assault upon her child or for failing to secure medical attention.

29. See N.Y. PENAL LAW $\S \S 500.05,500.10$ (Consol. 2004); N.Y. SOC. SERV. Law § 383$b(5)$ (Consol. 2004). Even if the prosecutor guesses correctly, immunity may not solve the problem. The immunized spouse still would have a privilege against testifying against his or her spouse. In New York, where only confidential communications remain privileged, the Heinonline -- 15 Ind. Int'l \& Comp. L. Rev. 94 2004-2005 


\section{B. Accomplice Liability}

Where two or more defendants are present and responsible for the care of a child at the time the child sustains non-accidental fatal injuries, both defendants may be found guilty of intentional or reckless homicide under a theory of accomplice liability, even if the prosecution cannot prove who was the active abuser and who was the passive abuser. In such a case there is sufficient evidence for the jury to infer that both parties either intended the fatal result, or because they were both present, were aware of the injury and of the risk of death and assisted in bringing it about. In a case like Wong, however, where the prosecution cannot prove exactly when the fatal abuse occurred or who was present, accomplice liability cannot be sustained. While it is clear in such a case that someone committed murder or manslaughter, unless both defendants can be proven guilty, neither can be convicted. ${ }^{30}$

Accomplice liability may also be sustained under so-called "accountability" statutes. ${ }^{31}$ Under these statutes, the failure to prevent child abuse will render the passive participant criminally liable as an accomplice for the active abuser's crime, whether for homicide or assault.

Three cases illustrate the application of accomplice liability principles. First, in Lane v. Commonwealth, ${ }^{32}$ a mother and her companion were prosecuted together under an accountability theory for assaulting her two-yearold daughter. Their defense was that the injuries resulted from an accidental fall down stairs. Lane was charged with aiding and abetting her companion to commit assault. The medical evidence showed that the victim had sustained many bruises, abrasions, and contusions, including a skull fracture. Lane was found guilty of complicity to commit assault in the first degree and her companion was found guilty of the assault. However, the trial judge set aside Lane's conviction on the ground that Lane had no legal duty to prevent the assault. $^{33}$

The Supreme Court of Kentucky affirmed the court of appeals' reversal of the trial court's ruling. The court of appeals held that parents have a legal duty to provide safety to their children. The majority found support in recently

immunized spouse might be compelled to testify against the other one. See N.Y. PENAL LAW $\S \S$ 500.05, 500.10; N.Y. SOC. SERV. LAw § 393-b(5) (2004); People v. Allman, 342 N.Y.S.2d 896 (N.Y. App. Div. 1973) (holding that because social services law suspends confidential communications privilege between husband and wife in proceedings involving child abuse, a wife may testify that she saw her husband hit their child and that he would not let her telephone for assistance); accord Adams v. State, 563 S.W.2d 804, 809 (Tenn. Crim. App. 1978) (holding that a wife may testify to husband's fatal assault on child as exception to privileged marital communication). But what would be the result? Still, a potentially guilty party would go free.

30. See, People v. Wong, 619 N.E.2d 377, 383 (N.Y. 1993).

31. See, e.g., State v. Fabritz, 348 A.2d 275 (Md. 1975) (relying on MD. ANN. CodE ART. $27 \S 35$ (a) (1982), current version at MD. CODE ANN. FAM. LAW art. 27, § 35(b) (Supp. 1986)); see also State v. Williquette, 385 N.W.2d 145 (Wis. 1986) (relying on WIS. STAT. $\$ 940.201$ (1985-1986)).

32. 956 S.W.2d 874 (Ky. 1997).

33. Id. at 875 . 
enacted statutes designed to protect a child's fundamental right to safety. ${ }^{34}$ The concurring justice found the duty in the common law, based upon the special relationship between a dependant child and his or her parents. ${ }^{35}$ In either event, the court found that the requirement of an actus reus was satisfied by the mother's failure to fulfill that duty. Moreover, the requisite accomplice mens rea was based on the defendant's knowledge or awareness of risk. The court held that a person who knows that his or her child is in a dangerous situation and fails to take action to protect the child presumably intends the consequences of the inaction, which is to facilitate the offense. ${ }^{36}$

Similarly, in Palmer v. State, ${ }^{37}$ the Supreme Court of Maryland upheld the conviction of a mother for involuntary manslaughter based on her "gross, or criminal, negligence in permitting her paramour to inflict, upon her twenty months' old child, prolonged and brutal beatings that finally resulted in the child's death ....,38 The court premised the mother's duty primarily on Maryland's nurturing statute, which requires parents to supply "support, care, nurture, welfare and education" to their children. ${ }^{39}$

Finally, in State v. Walden, ${ }^{40}$ a mother was convicted of aiding and abetting an assault solely on the ground that she was present when her child was assaulted but failed to take reasonable steps to prevent the assault. The court recognized a parental duty to take affirmative action to prevent harm to a child. ${ }^{41}$

These authorities would not support culpability in cases such as Wong. In these three cases, the prosecution was able to prove who was the active abuser

34. See Ky. REV. STAT. ANN. $§ 620.020$ (Michie 2004) (providing for a fundamental right to be free from personal injury); KY. REV. STAT. ANN. § 405.020 (Michie 2003) (duty to "nurture", which court held does not permit tolerance of personal injury); KY. REV. STAT. ANN. $\S 508.100$ (Michie 2004) (Criminal abuse in the first degree is committed when a person who has custody of a child intentionally permits the child to be placed in a situation that may cause him or her serious physical injury.).

35. Lane, 956 S.W.2d at 876-77 (Cooper, J., concurring).

36. Id. at 876; see also State v. Miranda, 715 A.2d 680 (Conn. 1998) (imposing accomplice liability for permitting a child to be assaulted).

37. 164 A.2d 467 (Md. 1960).

38. Id. at 468 .

39. Id. (quoting MD. CODE ANN., FAM. LAW. Art. 72 A, § 1 (1957 code), current version at $\S 5-203(2003))$.

40. 293 S.E.2d 780 (N.C. 1982).

41. Id. at 786.

We believe that to require a parent as a matter of law to take affirmative action to prevent harm to his or her child or be held criminally liable imposes a reasonable duty upon the parent. Further, we believe this duty is and has always been inherent in the duty of parents to provide for the safety and welfare of their children, which duty has long been recognized by the common law and by statute.

Id. at 785-86; see also Michael v. State, 767 P.2d 193 (Alaska Ct. App. 1988), rev'd on other grounds, Michael v. State, 805 P.2d 371 (Alaska 1991); P.S. v. State, 565 So.2d 1209 (Ala. Crim. App. 1990); People v. Peters, 586 N.E.2d 469 (Ill. App. Ct. 1991); People v. Peabody, 119 Cal. Rptr. 80 (Cal. Ct. App. 1975); State v. Adams, 557 P.2d 586 (N.M. Ct. App. 1976). 
of the child and who was the passive abuser. In Wong, that proof was missing In these three cases, the prosecution was able to prove that the passive defendant knew about the abuse or was aware of the risk of abuse, either because he or she witnessed the abuse or because of the visibility of the victim's injuries. In Wong, again, there was no such evidence. ${ }^{42}$

\section{Protection and Prevention Statutes}

Many jurisdictions recognize a separate non-homicide crime based on a common-law parental duty to prevent the abuse of a child, punishable with criminal penalties. Again, this duty is based on the special personal relationship between parents and children, and the fact that the parent has undertaken to provide safety to the child. Generically, that duty is violated when the defendant is aware of and consciously disregards a substantial and unjustifiable risk of death or injury. At that point, criminal penalties may be imposed under so called "failure to protect," "endangering the welfare," or "contributing to the dependency" statutes. ${ }^{43}$ In these jurisdictions, the passive parent is held criminally culpable not for the active abuser's conduct, but rather for his or her own conduct in, for example, permitting a child to be exposed to great bodily injury, ${ }^{44}$ neglecting a child, failing to provide medical care, ${ }^{45}$ exposing a child to abuse, ${ }^{46}$ or failing to report abuse of his or her child. ${ }^{47}$ These crimes generally are classified as misdemeanors, and carry lesser sentences than the homicide statutes, even where the underlying conduct causes a child's death. ${ }^{48}$ For this reason alone, they may be considered as an

42. 619 N.E.2d 377, 382-83 (N.Y. 1993).

43. See, e.g., Ala. STAT. § 26-15-1 (Michie 1992); ARIZ. REv. STAT. ANN. § 13-3619 (West 1978); 13-3623B; CAL. Penal Code $\$ 273$ (a) (West 1988 \& Supp. 1994); MinN. STAT. ANN. § 609.378(2)(b)(1-2) (West 1987 \& Supp. 1993); N.J. STAT. ANN. §§ 9:6-1 (West 1987), 2C:24-4(a) (West 1995).

44. See, e.g., State v. Peters, 780 P.2d 602, 606 (Idaho Ct. App. 1989); State v. Walden, 293 S.E.2d 780, 787 (N.C. 1982).

45. See, e.g., People v. Sally, 544 N.Y.S.2d 680, 681-82 (1989) (noting that by not securing medical treatment for a child while the child was being abused by his stepfather, resulting in injuries so severe that the defendant was aware that the child required medical attention, the defendant was guilty of violating the common law duty to protect).

46. See, e.g., N.Y. PENAL LAW § 260.10[2] (Consol. 2004). "A parent, guardian or other person legally charged with the care or custody of a child less than eighteen years old" is guilty if he or she "fails or refuses to exercise reasonable diligence in the control of such a child to prevent [the child] from becoming an 'abused child,' a 'neglected child,' a 'juvenile delinquent' ..." Id. One of the purposes of this statute is to establish "the duty of one parent to protect the child from the other parent." Id. See also People v. Carroll, 715 N.E.2d 500, 501 (N.Y. 1999) (quoting William C. Donnino, Practice Commentaries, in 39 MCKINNEY's Consol. LAWS OF N.Y. 348).

47. Seattle v. Eun Yong Shin, 748 P.2d 643 (Wash. Ct. App. 1988).

48. See, e.g., N.Y. PENAL LAW $\S 260.10$ (stating that endangering the welfare of a child is a misdemeanor, which carries a maximum sentence of one year incarceration); ARIZ. REV. STAT. ANN. $§ 13-3619$ (West 2004) (providing a class 2 misdemeanor for permitting life, health or morals of minor to be imperiled by neglect, abuse or immoral associations). But see, e.g., ARK. 
inadequate substitute where one of the defendants has clearly caused the death of a child.

For example, in People v. Carroll, $^{49}$ the New York Court of Appeals upheld a conviction for endangering the welfare of a child where the defendant, the stepmother of a child who was beaten to death by the father, failed to alert the authorities or summon medical assistance. The beatings occurred over the course of several days, and the defendant witnessed most of the violence. The court held that the evidence established that the defendant was acting as "the functional equivalent" of the child's parent at the relevant time, and had an obligation to take action to protect or help the child. ${ }^{50}$

In Wong, the proof would still have been inadequate to establish the defendants' liability under these statutes. Again, as with the accomplice liability cases, the active and passive abuser are each clearly identified, and there is proof, based on the timing, manner, and extent of the injuries inflicted, that the passive abuser had or should have had knowledge of the active abuser's conduct. In Wong, of course, this was the precise evidentiary gap. There was no evidence distinguishing the roles of the two defendants, no evidence of precisely when the fatal abuse was committed, and no evidence of who was present at the time. Accordingly, there was insufficient evidence that the passive defendant was aware of the risk of death, or that emergency medical assistance was required. ${ }^{51}$

\section{THE ENGLISH RESPONSE}

\section{A. The Wong Problem in England: Regina v. Lane}

In England, as in the United States, existing law provides that if the evidence shows that one of two accused must have committed a crime, but the prosecution cannot prove which of them committed it, both must be acquitted. ${ }^{52}$ This is true in cases of child abuse resulting in death, where two defendants are responsible for the care of a child. In Regina v. Lane, ${ }^{53}$ the court of appeal held that both defendants were required to be acquitted under these circumstances. ${ }^{54}$

CODE ANN. $§ 5-27-221$ (a)(3) (Michie 2004) (permitting that abuse of a minor is a class B felony if the abuse consists of sexual intercourse, deviate sexual activity, or caused serious physical injury or death; otherwise, it is a class $D$ felony).

49. 715 N.E.2d 500 (N.Y. 1999).

50. Id. at 502.

51. People v. Wong, 619 N.E.2d 377,383 (N.Y. 1993).

52. Regina v. Lane, 82 Crim. App. R. 5 (1986); Regina v. Bellman, 86 Crim. App. R. 40 (1988).

53. 82 Crim. App. R. 5 (1986).

54. Id. See also Aston and Mason 94 Crim. App R. 180 (1992), quoted in LAW CoMm'N, CHIIDREN: THEIR NON-ACCIDENTAL DEATH OR SERIOUS INJURY 282 (2003) [hereinafter Commission Report].

We have felt forced to come to the unwelcome conclusion that there was nothing in the evidence at the close of the prosecution case which indicated that one of the appellants rather than the other was responsible for inflicting the fatal injuries 
The facts in Lane are very similar to those in Wong, and create the same prosecutorial problems. There, a mother and stepfather were jointly responsible for the care of their child, who sustained a fractured skull sometime between noon and 8:30 p.m. Each parent had been absent from the home at times and present at times during this period. Both denied responsibility for the injuries.

The judge rejected the English equivalent of a motion to dismiss for failure to establish a prima facie case. The prosecution argued, and the court instructed the jurors, that they could draw an inference that both defendants were culpable because they both bore responsibility for the child. Neither defendant testified, and both were convicted. ${ }^{55}$ The court of appeals held that in the absence of evidence showing: (1) both defendants were present when the child was fatally injured; or (2) the non-striking parent was actively involved in the harm to the child, the jury should not have been invited to draw an inference that, in the absence of an innocent explanation, the parents were jointly responsible.

\section{B. Curing the Wong Problem in England}

Confronted with similar frightful statistics, ${ }^{56}$ and the same prosecutorial handicaps, the English government appointed a commission to study the issue. A comprehensive Law Commission Consultative Report on the subject, "Children: Their Non-Accidental Death or Serious Injury," followed. 57 Thereafter, legislation was passed creating a new crime called, "Causing or Allowing the Death of a Child or Vulnerable Adult." be adopted in the United States.

.... Nor can we find any evidence upon which the jury might have concluded that the two of them were acting in concert.

Id.

55. Lane, 82 Crim. App. R. at 5-11.

56. Commission Report, supra note 54 , at 15-18.

57. Id.

58. Domestic Violence, Crime and Victim's Act, 2004, c. 28, §§ 5-7. The English statute reads as follows:

(1) A person ("D") is guilty of an offence if-

(a) a child or vulnerable adult ("V") dies as a result of the unlawful act of a person who-

(i) was a member of the same household as V, and

(ii) had frequent contact with him,

(b) D was such a person at the time of that act,

(c) at that time there was a significant risk of serious physical harm being caused to $\mathrm{V}$ by the unlawful act of such a person, and

(d) either D was the person whose act caused V's death or--

(i) D was, or ought to have been, aware of the risk mentioned in paragraph (c),

(ii) D failed to take such steps as he could reasonably have been expected to take to protect $V$ from the risk, and

(iii) the act occurred in circumstances of the kind that $D$ foresaw or ought to have foreseen. 
(2) The prosecution does not have to prove whether it is the first alternative in subsection (1)(d) or the second (sub-paragraphs (i) to (iii)) that applies.

(3) If $D$ was not the mother or father of V--

(a) D may not be charged with an offence under this section if he was under the age of 16 at the time of the act that caused V's death;

(b) for the purposes of subsection (1)(d)(ii) D could not have been expected to take any such step as is referred to there before attaining that age.

(4) For the purposes of this section--

(a) a person is to be regarded as a "member" of a particular household,even if he does not live in that household, if he visits it so often and for such periods of time that it is reasonable to regard him as a member of it;

(b) where $\mathrm{V}$ lived in different households at different times, "the same household as V" refers to the household in which V was living at the time of the act that caused V's death.

(5) For the purposes of this section an "unlawful" act is one that--

(a) constitutes an offence, or

(b) would constitute an offence but for being the act of--

(i) a person under the age of ten, or

(ii) a person entitled to rely on a defence of insanity.

Paragraph (b) does not apply to an act of D.

(6) In this section-

"act" includes a course of conduct and also includes omission;

"child" means a person under the age of 16 ;

"serious" harm means harm that amounts to grievous bodily harm for the purposes of the Offences against the Person Act 1861 (c 100);

"vulnerable adult" means a person aged 16 or over whose ability to protect himself from violence, abuse or neglect is significantly impaired through physical or mental disability or illness, through old age or otherwise.

(7) A person guilty of an offence under this section is liable on conviction on indictment to imprisonment for a term not exceeding 14 years or to a fine, or to both.

Id. $\S 5$. Section 6 of the statute, entitled "Evidence and procedure" adopts the existing permissible negative inference based on silence and requires that the decision on the motion to dismiss for failure to state a case to answer be delayed until after all of the evidence has been presented. It reads as follows:

(1) Subsections (2) to (4) apply where a person ("the defendant") is charged in the same proceedings with an offence of murder or manslaughter and with an offence under section 5 in respect of the same death ("the section 5 offence").

(2) Where by virtue of section 35(3) of the Criminal Justice and Public Order Act 1994 (c 33) a court or jury is permitted, in relation to the section 5 offence, to draw such inferences as appear proper from the defendant's failure to give evidence or refusal to answer a question, the court or jury may also draw such inferences in determining whether he is guilty-

(a) of murder or manslaughter, or

(b) of any other offence of which he could lawfully be convicted on the charge of murder or manslaughter,

even if there would otherwise be no case for him to answer in relation to that offence.

(3) The charge of murder or manslaughter is not to be dismissed under paragraph 2 of Schedule 3 to the Crime and Disorder Act 1998 (c 37) (unless the section 5 offence is dismissed).

(4) At the defendant's trial the question whether there is a case for the defendant to answer on the charge of murder or manslaughter is not to be considered before 


\section{ADOPTING THE ENGLISH CURE}

\section{A. A New Substantive Offense}

The English statute creates a new crime that applies where: (1) a child dies as a result of unlawful conduct; (2) a member of the child's household caused the death, (3) the death occurred in anticipated circumstances; and (4) the defendant was or should have been aware of the risk, but either caused the death or did not take reasonable steps to prevent it. The prosecution does not need to show which member or members of the household actively caused the death and which passively failed to prevent it. This crime is categorized as a homicide offense.

Evidentiary and procedural changes also accompany the new law. Specifically, the jury may draw a negative inference against any defendant who fails to account for the manner of fatal injury either to the police or at trial. The decision on the motion to dismiss is then delayed until the close of all the evidence to allow either the defendants' statements, or the negative inferences against them, to be counted as part of the evidence in determining whether the prosecution has established a prima facie case. Once that proof is included, the motion to dismiss is rarely granted.

The new statute contains all of the elements that must be established before the state may punish conduct: actus reus, mens rea, and causation. The statute would also make it possible to establish liability for homicide by two or more persons responsible for a child when that child dies. The possibility of acquittal, dismissal, or conviction of a mere misdemeanor in such a circumstance could be avoided in many cases.

\section{Actus Reus}

Two issues arise concerning the actus reus, whether there is a duty to act and what evidence may be offered in defense of that duty.

\section{a. Duty to Act}

The statute recognizes a duty to provide a safe environment for a child. This includes not physically harming the child, as well as not failing to prevent harm of which a person responsible for the child was or should have been aware. The class of persons to whom the statute would apply would be narrower than that within the traditional universe of adults, who under the common law doctrine have a special relationship status that carries with it a duty to provide a safe environment for a child. ${ }^{59}$ Under the statute, only those

the close of all the evidence (or, if at some earlier time he ceases to be charged with the section 5 offence, before that earlier time)... .

Id. $\S 6$.

59. See Statute, supra note 58.

Heinonline -- 15 Ind. Int'l \& Comp. L. Rev. 101 2004-2005 
responsible adults who live in the victim's household are included. This would include the Wongs, in whose household the child lived for six days out of every week. It would also include a parent or step-parent who lives with the child, and the paramour or companion of a residential parent, assuming that person had frequent contact with the child. On the other hand, unlike traditional common law omission cases, the existence of a special status relationship would not be enough on its own to establish culpability under this statute. For example, a father or mother who did not reside and have frequent contact with the child at the time of the non-accidental injury could not be found guilty, despite the parental relationship, even if that parent was aware of a risk of serious injury.

Like existing protection and prevention statutes, this statute would also exclude public employees such as social workers or childcare workers. Under the new statute, these categories of outsiders will not be liable, since they are not members of the victim's household. The same will be true for doctors or nurses who come into contact with the child, however frequently. Moreover, the requirement that the defendant have "frequent contact" with the victim would prevent the liability of occasional visitors, paramours, guests, or those who happen to be present at the scene. ${ }^{60}$ This requirement, combined with the requirement that the death occur in anticipated circumstances, would also preclude a parent's liability for conduct by a stranger or transient visitor, of which he or she had no notice. Thus, the inattentive parent whose child is kidnapped from a playground and killed would not be held criminally responsible for the death.

\section{b. Defense to Failure to Act}

Under the statute, it would be a defense that the defendant "could not reasonably have been expected to take" steps to protect the child, because, for example, to do so would have subjected him or her to serious physical injury. A defendant should be convicted under this statute only where the prosecution proves that any reasonable person in the defendant's position would have taken action. Indeed, "in the commonplace situations in which offences are committed against children it will be a matter of obvious common sense to identify what it was reasonable to expect the responsible person to do."61

This provision has two collateral benefits. First, it permits a battered spouse, generally a mother, to interpose a defense to the crime that does not exist in all U.S. jurisdictions. ${ }^{62}$ That is, the battered woman would be

60. See, e.g., Johnson v. State, 506 S.E.2d. 374 (Ga. 1998) (holding that defendant could not be found liable for fatal abuse of a child where he spent the night downstairs at his sister's while sister and boyfriend killed child upstairs). Id.

61. Commission Report, supra note 54, at 55.

62. For a complete discussion of existing failure-to-protect legislation and how it fails to consider the battered spouse's circumstances, see V. Pualani Enos, Recent Development: Prosecuting Battered Mothers: State Laws' Failure to Protect Battered Women and Abused 
permitted to prove her own abuse in her defense, and then argue that a reasonable person in her circumstances could not have taken action to prevent the death. A full-blown duress defense would not be required. ${ }^{63}$ Second, the existence of this defense might also encourage the passive abuser to give her account of how the child died. This might in turn result in more exposure and even prosecutions of batterers. Third, proof of other violence would be available for the jury to consider on any accompanying count of murder or manslaughter that the defendant and any co-defendant also faced. ${ }^{64}$

\section{Mens Rea: Intent or Awareness of Risk}

The mens rea requirement for liability under the statute is satisfied by proof that the defendant either (1) intentionally harmed the child or (2) had notice of a high level of risk of serious physical harm to the child. The "intent" standard is the traditional intent required for general criminal culpability. ${ }^{65}$ The standard covers the active abuser and the accomplice to active abuse.

The awareness-of-risk standard is applicable to the passive abuser. It contains both an objective and subjective element, and would cover two categories of defendants: (1) a person in the defendant's circumstances who is aware of or ought to be aware of the risk of serious physical harm being caused by an unlawful act by someone (i.e., the responsible adult who is careful enough to be aware of the risk but does not act reasonably to prevent the result), and (2) the responsible adult who is not aware because he or she is culpably inattentive. ${ }^{66}$ The test is not whether a "reasonable person" would be aware of the risk of death to the child. Instead, the test is whether a reasonable person in the defendant's situation would be aware of a significant risk of serious physical harm. ${ }^{67}$

As noted above, an additional mens rea requirement is that the offense be committed in the kind of circumstances the person anticipated or should have

Children, 19 HARV. WOMEN's L.J. 229 (1996) (arguing, inter alia, that the failure to employ a "reasonableness" standard in favor of strict liability for the passive parent is improper).

63. Michelle S. Jacobs, Requiring Battered Women Die: Murder Liability for Mothers Under Failure to Protect Statutes, 88 J. CRIM. L. \& CRIMINOLOGY 579, 587 (1998); see also Wayne R. LafaVe \& AuSTiN W. ScotT, JR., Criminal LaW 208-09 (2d ed. 1986). Courts have not yet identified what acts would be considered to put parents in sufficient danger to excuse their failure to protect a child, probably because such evidence generally would result in an acquittal.

64. Commission Report, supra note 54, at 96.

65. Generically, a person intends a result when it is his or her conscious purpose to bring it about. See Black's Law Dictionary 314 (7th ed. 2000).

66. Commission Report, supra note 54, at 53.

67. This is consistent with protection and prevention statutes that consider the culpability of a battered or abused spouse. See, e.g., State v. Williquette, 385 N.W.2d 145 (Wis. 1986) (providing an objective standard for determining what constitutes child abuse and doing away with the requirement of other mens rea); State v. Walden, 293 S.E.2d 780, 787 (N.C. 1982) ("The failure of a parent who is present to take all steps reasonably possible to protect the parent's child from attack by another person constitutes an act of omission by the parent showing the parent's consent and contribution to the crime being committed."). 
anticipated, and by a person who lives with and who has frequent contact with the child. It is not sufficient that there be awareness of a risk that a child might be the victim of some intervening offense, or some offense by someone who does not live with the child. For example, there would be no liability for a grieving parent whose child is kidnapped while playing out of the parent's sight, even if the parent had been culpably inattentive. Nor would there be liability for a parent who allows a child to be alone with an abusive parent, where the child is harmed by another individual during that time. The risk is of anticipated, deliberately inflicted harm as a result of an illegal act.

This statute would support the culpability of both parties regardless of whether the prosecution can establish who is the active and who is the passive abuser, so long as the injury to the child was visible to both parties. Thus, in Lane, where the infant suffered physical injuries, the defendants could now be held liable even without proof of their respective roles, because whoever was the passive abuser would or should have been aware of the risk of serious physical injury. In addition, awareness of a risk of serious physical injury could be established by proof of a pattern of continuing abuse or of prior serious abuse, of which the passive defendant would have been aware.

It is not clear, however, that the proof in Wong could have satisfied this statute. Wong was not a case, like Lane, in which the visible nature of the child's injuries would reasonably have been noticed by someone in the defendants' circumstances. Indeed, Wong presents the almost unique circumstance in which the prosecution lacked proof not only of when the baby was fatally harmed, but also of who was present when the harm occurred. In Wong, the prosecution also could not prove that anyone not present at the moment of abuse would have been aware of the injury or of the need to act, because, uniquely, the injury left no external bruises. Indeed, the Court of Appeals specifically noted that the symptoms of shaken baby syndrome-a gradual fall into a comatose state with no external injuries-could easily be mistaken for the quieting down of the child. ${ }^{68}$

\section{Causation}

To establish culpability under the statute, proof of causation must, of course, be present. Generally, this should not be difficult for the prosecution to prove. There will almost always be medical testimony that the child died of non-accidental causes. Under the statute, this proof would be sufficient to support the liability of both defendants. Thus, in Palmer v. State, ${ }^{69}$ the court affirmed a mother's involuntary manslaughter conviction for negligently

68. See People v. Wong, 619 N.E.2d 377 (N.Y. 1993). For cases like Wong, the evidentiary and procedural changes suggested in the statute-a negative inference based on a duty to account for the non-accidental death of a child, and the accompanying delay of the motion to dismiss to permit that account or the inference from its absence-would be required.

69. 164 A.2d 467 (Md. 1960).

Heinonline -- 15 Ind. Int'l \& Comp. L. Rev. 104 2004-2005 
permitting her child to be abused even though she was not the active abuser. The court reasoned that "to constitute the cause of the harm, it is not necessary that [the mother's] act be the sole reason for the realization of the harm which has been sustained by the [child.]" harm, the court reasoned that the mother indirectly contributed to the abuse. Where liability is premised on a failure to promptly secure medical treatment or care, the proof that frequently exists in prosecutions now-that earlier medical attention would have averted the death-would also be sufficient to establish that the conduct of the passive defendant was a proximate cause of death.

In conclusion, in those cases where it is not possible to establish traditional intent or accomplice liability, the statute would provide an alternative homicide statute under which to secure a conviction. In addition, where it is not possible to identify which of two or more defendants was the active or passive abuser, the statute permits a finding of criminal culpability for both, so long as there is evidence to establish sufficient awareness of risk on behalf of both defendants, either because of the defendant's presence at the time of the abuse, the visible nature of the injuries sustained, or a past history of abuse. In the unique circumstance where the prosecution cannot prove when the abuse occurred or who was present, and where the abuse leaves no visible signs, the new statute will probably not be successful absent adoption of the proposed procedural and evidentiary changes that are discussed below.

\section{B. Drawing a Negative Inference From the Failure to Account for the Non-Accidental Death of a Child}

\section{English Law}

The English statute provides that the court and jury be allowed to draw a negative inference against any defendants who fail to give a statement before or at trial concerning how the child's death occurred. Although this may appear shocking to the U.S. reader, the law in England has allowed such an inference to be drawn in all criminal cases for at least a decade.

Unlike in the United States, in England the right to remain silent is not absolute. Pursuant to the Criminal Justice and Public Order Act 1994 § 35(3) ("CJPOA"), a jury may draw "such inferences as appear proper" against a defendant who: (1) remains silent or fails to answer a question during questioning by the police after being properly cautioned; (2) remains silent at trial; or (3) proves facts at trial inconsistent with those given in response to earlier police questioning. ${ }^{71}$

70. Id. at 474 (quoting 1 Charles E. Wharton, Criminal LaW AND Procedure 68 (2d ed. 1976).

71. Criminal Justice and Public Order Act, 1994, $\$ 34$ (Eng.). The English statute provides, in substance, that where a defendant gives evidence and relies on a fact he or she failed to mention to the police, or if a defendant does not give evidence or gives evidence but unreasonably refuses to answer a question, the court or jury may again draw such inference as 
Under the statute, when a defendant is charged with murder or manslaughter and the new criminal offense, the jury may draw a negative inference against the defendant as to all charges when that defendant either fails to account for the homicide to the police, fails to give an account at trial, or gives an account at both times but those accounts are inconsistent.

The legality of the CJPOA inference under the European Code of Human Rights, and the ways in which it has been implicated, are beyond the scope of this article. ${ }^{72}$ It is sufficient to note that the proposed statute would allow the drawing of the inference against a silent defendant both as to the crime of causing or allowing the death of a child, and as to any accompanying charge of homicide.

\section{The Negative Inference under U.S. Law}

\section{a. Drawing a Negative Inference Based on a Duty to Report}

In cases like Wong, prosecuted under the new statute, where the prosecution can prove the non-accidental death of a child, can narrow down the group of responsible parties, but cannot prove the defendants' relative guilt, the duty to provide a safe environment for a child should be construed to include the duty to account for that child's non-accidental death. The failure to so account could then permit a negative inference against the non-reporting defendant. This was a solution proposed by the Commission in England; ${ }^{73}$ however, this solution does not appear in the final statute submitted to the Queen. Instead, Parliament simply relied on the existing statutory inference from silence and proposed a delay in the motion to dismiss so that this inference could form part of the prosecution's prima facie case.

Statutes creating a duty to report child abuse already exist in every state of the United States, and extend the duty to doctors, nurses, and others who are likely to be in a position to report child abuse. Under these statutes, a person

appear proper. $I d$. As to facts that the defendant did mention on being questioned and could reasonably have been expected to mention, the court or jury may draw such inferences from the failure as appear proper. Id. Section $38(3)$ prohibits a conviction based solely on such an inference. Id. $\S 38(3)$. These sections have been upheld by the European Court of Human Rights (ECHR).. See, e.g., Condron v. United Kingdom 31 Eur. Ct. H.R. 1 (2001); Murray v. United Kingdom 22 Eur. Ct. H.R. 29 (1996).

72. The ECHR has held that the limitations on the right to silence are consistent with the European Code of Human Rights. Commission Report, supra note 54, at 40-43. It was the Commission's position, as well, that Article 6 would not be violated because of: (1) the fundamental importance of the duty owed to the child under Articles 2 and 3; (2) the unsatisfactory state of the current law; (3) the safeguards described before a jury may draw a negative inference; and (4) the fact that the jury must be sure of the defendant's guilt before convicting. Id. Finally, the Commission recommended that a trial judge be under a duty to withdraw the case form the jury when he considers that any conviction would be unsafe or the trial would otherwise be unfair. The Commission explicitly noted that this safeguard might be particularly important if an adverse inference from silence was likely to be an important factor in the jury's considerations. Id.

73. Id. at 35-36. 
can be prosecuted for failing to report suspected abuse. ${ }^{74}$ These statutes reflect a unanimous recognition that child abuse is a problem of staggering dimension, and that children can be better protected by encouraging reporting. ${ }^{95}$ Indeed, in some jurisdictions, a parent's failure to account for abuse of a child is considered proof that the family situation is unlikely to change for the better, and is thus part of the basis for terminating parental rights. ${ }^{96}$ Moreover, as previously discussed in Part II, some states hold parents criminally liable for failing to prevent abuse (by reporting or otherwise), either under an aiding and abetting theory for homicide or assault, or under a protection and prevention statute. ${ }^{97}$ Thus, the duty to report already exists in some form.

As part of the new statute, a presumption should be created that would permit the jury to draw a negative inference against one of multiple defendants charged under the statute where that defendant has failed to account for the non-accidental death of a child. The inference would be based on the responsible defendant's duty to account consistent with that defendant's Fifth Amendment privilege. Thus, the failure to account for the non-accidental death would be sufficient to provide an inference that the reason for the failure is that the account would be self-incriminatory.

California $v$. Byers ${ }^{78}$ is the Supreme Court's major statement on the constitutionality of duty-to-report statutes. Byers was a plurality opinion written by Chief Justice Burger, where the Court analyzed a California statute requiring any driver involved in a vehicular accident that resulted in property damage to stop at the scene and leave his or her name and address. Although the so-called "stop and identify" statute was potentially self-incriminatory, the Court upheld it. $^{79}$

The Court began its analysis by noting that it was "balancing the public need on the one hand, and the individual claim to constitutional protections on

74. See Caroline Trost, Note: Chilling Child Abuse Reporting: Rethinking the CAPTA Amendments, 51 VAND. L. REV. 183 n.63 (1998).

75. See, e.g., TENN. CODE. ANN.. § 37-1-402(a) (1996).

The purpose of this part is to protect children whose physical or mental health and welfare are adversely affected by brutality, abuse or neglect by requiring reporting of suspected cases by any person having cause to believe that such case exists. It is intended that, as a result of such reports, the protective services of the state shall be brought to bear on the situation to prevent further abuses, to safeguard and enhance the welfare of children, and to preserve family life. This part shall be administered and interpreted to provide the greatest possible protection as promptly as possible for children.

Id. See also N.J. STAT. ANN. §§ 9:6-8.8 (West 1993) (providing "for the protection of children ... who have had serious injury inflicted upon them by other than accidental means").

76. See, e.g., West Virginia Dep't. of Health and Human Res. ex rel. Wright v. Doris S., 475 S.E.2d 865 (W. Va. 1996); Adoption of Larry, 750 N.E.2d 475 (Mass. 2001).

77. See discussion supra Part II.

78. 402 U.S. 424 (1971).

79. Id. at 432 . 
the other," and that "neither interest can be treated lightly.,"80 Reviewing other duty-to-report requirements, the Court noted:

In each of these situations there is some possibility of prosecution-often a very real one-for criminal offenses disclosed by or deriving from the information that the law compels a person to supply. Information revealed by these reports could well be "a link in the chain" of evidence leading to prosecution and conviction. But under our holdings the mere possibility of incrimination is insufficient to defeat the strong policies in favor of a disclosure called for by statutes like the one challenged here. ${ }^{8}$

Reviewing its precedent, the Court explained that the question is not the possibility of incrimination, but whether the duty to report presents a "substantial hazard of self-incrimination." depends on the answers to the following questions: (1) is the statute aimed at the public at large or at a "highly selective group inherently suspect of criminal activities," ${ }^{, 83}(2)$ is the statutory purpose "essentially regulatory" or is it aimed at facilitating the criminal conviction of the reporter; and (3) is the statute designed to disclose inherently illegal activity of the reporter? ${ }^{84}$

In Byers, the Court concluded that the statute was aimed at a sufficiently large portion of society (drivers involved in accidents) that it could not be deemed to address a "highly selective group inherently suspect of criminal activities." The fact that it was aimed at accident participants, many of whom, like Byers, might be guilty of criminal conduct, did not change the fact that driving, and even being involved in an accident, does not necessarily involve criminal conduct. ${ }^{85}$ As to the second criterion, the Court noted that despite the collateral criminal consequences of disclosing one's name and address, and the possibility that this increased the likelihood of prosecution, the statute's main purpose was essentially to regulate motor vehicle use. The duty to report-that property damage has occurred-indicated that the duty's purpose was properly to impose responsibility for economic compensation for any property damage. ${ }^{86}$

80. Id. at 427 .

81. Id. at 428.

82. Id. at 429 (quoting U.S. v. Sullivan, 274 U.S. 259 (1927)).

83. Id. (quoting Albertson v. SACB, 382 U.S. 70, 79 (1965)).

84. Id. at 430.

85. Id. at 431 . Compare Albertson, 382 U.S. at 79 (holding that an order requiring registration by members of communist organizations violates the Fifth Amendment); Haynes v. United States, 390 U.S. 85 (1968) (holding that an order requiring registration of firearm involved inherently criminal activity and therefore violated the Fifth Amendment).

86. The Court explained:

Although identity, when made known, may lead to inquiry that in turn leads to arrest and charge, those developments depend on different factors and independent evidence. Here the compelled disclosure of identity could have led 
Similarly, although the statute might provide a link in the chain of evidence needed to prosecute for criminal conduct that may have occurred, the Court held that the driver's self-reporting would not be the sole evidence against a driver in any criminal case. In short, the Court concluded:

The disclosure of inherently illegal activity is inherently risky. Our decisions in Albertson and the cases following illustrate that truism. But disclosure with respect to automobile accidents simply do not entail the kind of substantial risk of self-incrimination involved in Marchetti, Grosso, and Haynes. Furthermore, the statutory purpose is noncriminal and selfreporting is indispensable to its fulfillment. ${ }^{87}$

The Court applied its analysis in Byers in a case where the safety of a child was at issue. Again, the Court upheld the duty to report.

In Baltimore City Dep't of Social Servs. v. Bouknight ${ }_{2}^{88}$ in a seven-judge majority decision authored by Justice O'Connor, the Court held that a parent's duty to produce a child in response to a court order trumps the parent's right against self-incrimination, even in a case where the authorities suspect that the child has been murdered by the parent. ${ }^{89}$ In Bouknight, a mother who had custody of her child pursuant to a court order refused to comply with another court order to produce her child. The authorities believed the child had been abused and had died as a result. The Maryland Court of Appeals struck the lower court's order holding the mother in contempt on grounds that the act of production forced Bouknight to admit "a measure of continuing control and dominion over Maurice's person in circumstances in which 'Bouknight has a reasonable apprehension that she will be prosecuted." found the contempt order unconstitutional. ${ }^{91}$

Again, as in Byers, despite the obvious self-incriminatory implications of the duty to produce a child under the circumstances presented, the Supreme Court reversed and held that Bouknight could not invoke her Fifth Amendment right against self-incrimination to resist the order to produce her child. ${ }^{92}$ The

to a charge that might not have been made had the driver fled the scene; but this is true only in the same sense that a taxpayer can be charged on the basis of the contents of a tax return or failure to file an income tax form. There is no constitutional right to refuse to file an income tax return or to flee the scene of an accident in order to avoid the possibility of legal involvement. Byers, 402 U.S. at 434.

87. Id. at 431 . Interestingly, Byers was indeed later charged with the substantive criminal offense of overtaking another vehicle. Id. at 424.

88. 493 U.S. 549 (1990).

89. For the purposes of the decision, the Court assumed that the act of production was testimonial in nature. Id. at 555.

90. Id. at 554 (quoting In re Maurice M, 550 A.2d 1135, 1141 (Md. 1988)).

91. Bouknight, 493 U.S. at 554.

92. Id. at 562 . 
Court used the same three-part test it used in Byers to determine if the duty violated the Fifth Amendment.

First, the Court found that persons who care for children pursuant to custody orders are not members of "a selective group inherently suspect of criminal activities" even though they may have been found by the court to be unable to give proper care to a child. ${ }^{33}$ Second, it found that the statute did not "focu[s] almost exclusively on conduct which is criminal." ${ }^{94}$ Even though the mother was suspected of criminal activity, the Court explained:

Even when criminal conduct may exist, the court may properly request production and return of the child, and enforce that request through exercise of the contempt power, for reasons related entirely to the child's well-being and through measures unrelated to criminal law enforcement or investigation. ${ }^{95}$

Finally, the Court observed that it was "not called upon to define the precise limitations that may exist upon the State's ability to use the testimonial aspects of Bouknight's act of production in subsequent criminal proceedings." 96 It did note, however, that using immunity "is not appropriate where a significant element of the regulatory requirement is to aid law enforcement." 97

Using the Byers and Bouknight criteria, imposing a duty on an individual to account for the non-accidental death of a child for whom he or she is responsible should survive Fifth Amendment scrutiny. First, the duty to account is directed toward parents, or those standing in responsible positions to children. This is not a "highly select group inherently suspect of criminal activity." caretakers whose children have been abused, the same argument was made in Byers and Bouknight - that the statute was aimed at criminal activity (drivers who caused accidents or caretakers who abused their children) and thus at people who were likely to be found to have engaged in criminal conduct. That argument was rejected because the Court found no necessary correlation between causing an accident and criminal conduct ${ }^{99}$ or between having court ordered child custody because of deficient parenting and criminal conduct. ${ }^{100}$ Similarly, the fact that one reports that one's child has been killed does not necessarily mean that the reporter has himself or herself engaged in criminal

93. Id. at 559-60 (quoting Marchetti v. United States, 390 U.S. 39, 57 (1968) (quoting Albertson v. SACB, 382 U.S. 70, 79)).

94. California v. Byers, 402 U.S. 424, 454 (1971) (Harlan, J., concurring).

95. Bouknight, 493 U.S. at 561.

96. Id.

97. Id. at 562 .

98. Byers, 402 U.S. at 429.

99. See supra note 83 and accompanying text.

100. See supra note 92 and accompanying text.

Heinonline -- 15 Ind. Int'l \& Comp. L. Rev. 110 2004-2005 
conduct. Indeed, it is more likely that the act of reporting will be proof that the caretaker has not engaged in any crime either as an accomplice or for failure to protect. In addition, in many states, these individuals already have a civil duty to account for harm to a child.

Second, the proposed duty to account could be sustained as having a regulatory purpose besides facilitating the reporter's criminal conviction. Indeed, the proposed duty to account would be no more than an extension of the existing statutory duties to report that apply to third parties. The purpose of the duty is to protect children from harm at the hands of their caregivers by both encouraging reporting and accurately identifying the abusers. Third, the proposed duty is not impermissibly designed to "disclose the illegal acts of the reporter." 101 In fact, the duty is aimed at exposing the culpability of the active abuser who causes the child's death.

Finally, under U.S. law, the safeguards accompanying the drawing of the inference in the criminal context may be sufficient to minimize the impact on the Fifth Amendment right, thus protecting the right against self-incrimination. To be sure, the defendant must be advised of the permissible inference when questioned by the authorities; this would be added to the standard Miranda warnings where the non-accidental death of a child is suspected.

\section{b. The Supreme Court's No-Inference Precedent}

Having established a duty to account for the non-accidental death of a child, the jury should be allowed to draw a negative inference against a nonreporting defendant during a prosecution under the new statute. The inference is supported by the following factors: (1) the importance of protecting children from murder at the hands of those who are supposed to care for them; (2) the fact that the inference rests on a substantive, common-law duty to provide safety; (3) the limited circumstance under which the inference would be available, that is, only where the prosecution cannot prove the guilt of two or more responsible parties for the death of a child for whom they were responsible. Under these circumstances, the drawing of the inference should be sustained under the Fifth Amendment.

The Fifth Amendment provides, in relevant part, "No person ... shall be compelled in any criminal case to be a witness against himself ...." In Griffin v. California ${ }^{102}$ the Supreme Court held that neither a court nor a prosecutor may comment on a defendant's silence. Under Griffin, no negative inference whatsoever may be drawn from the defendant's silence because such an inference would chill the defendant's exercise of that right by making its exercise costly. ${ }^{103}$

101. See supra note 92 and accompanying text.

102. 380 U.S. 609 (1965).

103. Id. at 615 . 
The Supreme Court has adhered to this conclusion. Sixteen years after Griffin, in Carter v. Kentucky, the Court reaffirmed that a defendant has a right to have an instruction given to the jury that the jury may not draw any inferences from the defendant's failure to testify. ${ }^{104}$ Moreover, in the 1999 case of Mitchell $v$. United States ${ }_{2}{ }^{105}$ the Court, by a five-to-four majority, extended the no-comment rule to sentencing proceedings, refusing to allow a judge to rely on a defendant's failure to contest certain factual assertions that served to increase her sentence. The majority eloquently (and quite relevantly to a comparative analysis) defended the no-adverse-inference rule as follows:

The rule against adverse inferences is a vital instrument for teaching that the question in a criminal case is not whether the defendant committed the acts of which he is accused. The question is whether the Government has carried its burden to prove its allegations while respecting the defendant's individual rights. The Government retains the burden of proving facts relevant to the crime at the sentencing phase and cannot enlist the defendant in this process at the expense of the self-incrimination privilege. ${ }^{106}$

To be sure, the Supreme Court has chosen to stick to its no-adverseinference rule. Indeed, as the quote from Mitchell implies, one difference between the United States and other countries (including England) is that the United States remains a resolutely rights-based, accusatorial system. ${ }^{107}$ Before the recent domestic adoption of the ECHR, England was not a rights-based system by any means. Although England recognized many rights of accused persons similar to the United States, it has no written constitution or bill of rights. Moreover, as a monarchy, English judicial process has remained more inquisitorial than the U.S. system, with more emphasis on the obligations of its citizens as subjects than in the United States. The U.S. system is still built upon protecting against conviction of the innocent and limiting the authority of the sovereign rather than viewing its citizens as subjects.

Nevertheless, consistent with the Fifth Amendment, a defendant charged with the new crime of causing or allowing the death of a child should have a substantive duty to account for the death of the child. Where it is clear that someone has caused the non-accidental death of a child, and where the prosecution cannot otherwise prove its case (such as in the circumstances of Wong and Lane), the Court should uphold a negative inference against the nonreporting defendant. Like juries in England, a U.S. jury would be instructed that it could consider the non-reporting defendant's failure to account for the

104. Carter v. Kentucky, 450 U.S. 288 (1981), remanded to 620 S.W.2d 320 (Ky. 1981).

105. 526 U.S. 314 (1999).

106. Id. at 330.

107. Id.

Heinonline - 15 Ind. Int'1 \& Comp. L. Rev. 112 2004-2005 
child's death. If the jury believes the failure to account is based on the fact that the defendant is responsible for the death under the new statute, then the jury could draw the negative inference. The jury could also consider the defendant's explanation for his or her failure to account in evaluating whether to draw a negative inference. As in England, the jury would also be instructed that it could not base a verdict of guilty on the inference alone. And, as in England, the court would retain the power to vacate a conviction if it concluded that the inference played too large a role in the jury's verdict.

\section{c. Delaying the Decision on the Motion to Dismiss}

Finally, what of the statutory provision delaying the decision on whether there is a case to answer until the close of all of the evidence? Like the U.S. motion to dismiss at the end of the prosecution's case, in England there is a procedural rule that requires a judge to dismiss a case at the close of the prosecution's case where a properly directed jury could not convict (there is "no case to answer"). ${ }^{108}$ According to the Commission, it is the operation of this rule that prevents the prosecution from properly convicting those responsible for child abuse, because under traditional principles the evidence is insufficient at the close of the prosecution's case to establish the defendant's relative culpability. As the Commission noted, the requirement that this decision be made after the close of the prosecution's case makes no logical sense in a child abuse case, where the only witness (because the child is dead or too young to speak) is the defendant, who by that time will not have been heard from. Thus, the Commission recommended that the decision whether to send the case to the jury be made only after the defendant's case. That is, the often taken-for-granted procedure should be changed to abolish the decision on whether there is a case to answer, and to substitute the decision whether the case should go to the jury, which decision would properly be made at the end of all of the evidence.

Delay of the motion to dismiss would likely survive constitutional scrutiny in the United States. To be sure, a defendant is entitled to a determination that the prosecution has established a prima facie case in which the evidence is sufficient to go to the jury. ${ }^{109}$ While it is preferable for the motion to be made at the end of the prosecution's case, so that the defendant knows whether he should attempt to rebut the prosecution's case, the determination of sufficiency can be reserved until after the jury verdict and can be made until seven days after the jury has been discharged. ${ }^{10}$ Thus, under U.S. law, there would be no constitutional barrier to delaying the motion to dismiss until after the close of all of the evidence.

108. Galbraith [1981] 1 W.L.R. 1039.

109. Jackson v. Virginia, 443 U.S. 307 (1979).

110. FED. R. CRIM. P. 29(c). 


\section{CONCLUSION}

This article supports the enactment in the United States of a statute similar to England's new statute. Like its English counterpart, this statute would impose the same criminal responsibility on each member of a small, definable group of members of a deceased child's household for the child's non-accidental death and would not require proof as to which person was the active or passive abuser. The new offense would be classified as a homicide offense. It would establish culpability for homicide, but the sentence would be less than that for other homicides. At the very least, then, the statute would impose a sentence that is greater than that currently available under Endangering the Welfare of a Child statutes, which are misdemeanors in most jurisdictions even where the defendant's conduct causes death. ${ }^{111}$ At the same time, this new statute would prevent acquittal in those jurisdictions that do not recognize omission liability for failure to prevent abuse or to seek medical assistance.

In other cases, however, the key to successful prosecution is the drawing of a negative inference from the failure to account and the delay of the motion to dismiss. Under established Supreme Court precedent, the U.S. courts could recognize an evidentiary inference against a defendant who fails to account for the death of a child for whom he or she is responsible under the proposed statute that would be permissible in a case in which the defendants are charged under the statute. A proper balance of the state's interest in and need for the inference and the limited incursion on the Fifth Amendment right to remain silent would prevent the acquittal of all parties where it is clear that one or both of them are responsible for murdering a helpless child. 